\title{
Gas Exchange and Chlorophyll Content of 'Tifblue' Rabbiteye and 'Sharpblue' Southern Highbush Blueberry Exposed to Salinity and Supplemental Calcium
}

\author{
Glenn C. Wright ${ }^{1}$ \\ Department of Horticultural Sciences, Texas A\&M University, College Station, TX 77843-2133
}

Kim D. Patten ${ }^{2}$

Texas A\&M University Agricultural Research and Extension Center at Overton, P.O. Drawer E, Overton, $T X 75684$

\author{
Malcolm C. Drew ${ }^{3}$ \\ Department of Horticultural Sciences, Texas A\&M University, College Station, TX 77843-2133 \\ Additional index words. mineral nutrition, salt stress, salinity, photosynthesis, transpiration, stomatal conductance, Vaccinium \\ ashei, Vaccinium corymbosum
}

\begin{abstract}
Tifblue' rabbiteye blueberry (Vaccinium ashei Reade) and 'Sharpblue' southern highbush blueberry (primarily $V$. corymbosum) were treated with 0,25 , or $100 \mathrm{Mm} \mathrm{Na}^{+} \mathrm{as}_{2} \mathrm{SO}_{4}$ or $\mathrm{NaC1}$, and $\mathrm{0}, 1,3$, or $10 \mathrm{Mm}$ supplemental Ca ${ }^{2+}$ in sand culture in the greenhouse. Greatest stomatal conductance $\left(\mathrm{g}_{\mathrm{s}}\right)$ and net assimilation (A) occurred in unsalinized 'Tifblue' plants not given additional $\mathrm{Ca}^{2+}$. Stomatal conductance, $\mathrm{A}$, transpiration $(\mathrm{E})$, and xylem water potential( $\left.\Psi_{*}\right)$ of 'Tifblue' and 'Sharpblue' plants were all lowered as salinity increased, and these effects were more pronounced with NaCl than with $\mathrm{Na}_{2} \mathrm{SO}_{4}$. After 63 days, for plants given $100 \mathrm{Mm} \mathrm{Na}{ }^{+}$as $\mathrm{NaCl}, \mathrm{g}_{s}$ and net assimilation rate were reduced to only $10 \%$ of the unsalinized controls, while for plants salinized with $100 \mathrm{~mm} \mathrm{Na}^{+}$as $\mathrm{Na}_{2} \mathrm{SO}_{4}$, $\mathrm{g}_{s}$ and $\mathrm{A}$ were $35 \%$ and $43 \%$, respectively, of unsalinized controls. Leaf necrosis was more extensive on 'Sharpblue' plants given NaCl than on 'Tifblue' plants. Neither $\mathrm{Ca}^{2+}$ nor $\mathrm{Na}^{+}$treatments led to severe chlorosis; reductions in leaf chlorophyll content were mainly due to necrosis. $\mathrm{The} \mathrm{Na}^{+}$ induced reduction in gas exchange was associated with negative $\Psi_{w}, \mathrm{Ca}^{2+}$ deficiency, or a combination of these factors. Additional factors leading to inhibition of gas exchange in $\mathrm{NaCl}$ stressed plants include $\mathrm{Cl}$ toxicity and leaf necrosis. Calcium supplements were unable to ameliorate $\mathrm{NaCl}$ damage in 'Tifblue' or 'Sharpblue' plants, possibly because of the inability of $\mathrm{Ca}^{2+}$ to counter $\mathrm{Cl}$ entry and toxicity. In contrast, additional $\mathrm{Ca}^{2+}$ improved $\mathrm{g}_{s}, \mathrm{~A}_{3} \Psi_{w}$, and leaf chlorophyll content of 'Tifblue' plants that received $\mathrm{Na}_{2} \mathrm{SO}_{4}$. For plants treated with $25 \mathrm{~mm} \mathrm{Na}{ }^{+}$as $\mathrm{Na}_{2} \mathrm{SO}_{4}$ and $1 \mathrm{~mm} \mathrm{Ca}^{2+}$, $\mathrm{g}_{\mathrm{s}} \mathrm{was} 1.5$ to 2.5 times higher than in plants without added $\mathrm{Ca}^{2+}$. Low $(1 \mathrm{mM})$ concentrations of $\mathrm{Ca}^{2+}$ were more effective in ameliorating the effects of $100 \mathrm{~mm} \mathrm{Na}^{+}$as $\mathrm{Na}_{2} \mathrm{SO}_{4}$. than were 3 or $10 \mathrm{~mm} \mathrm{Ca}^{2+}$ supplements, possibly because higher $\mathrm{Ca}^{2+}$ concentrations damaged the metabolism of the calcifuge blueberry.
\end{abstract}

\begin{abstract}
Blueberries require high quality irrigation water to thrive. Poor ground water quality has impeded blueberry expansion in the southeastern United States, where sufficient good quality water may not be available throughout the season. Irrigation water in eastern Texas often exceeds $15 \mathrm{~mm} \mathrm{Na}^{+}, 6 \mathrm{~mm} \mathrm{Cl}$, and $10 \mathrm{~mm}$ $\mathrm{HCO}_{3}$ (Texas Dept. of Health, 1990). Water $\mathrm{pH}$ levels >7.0, total bicarbonates $\left(\mathrm{HCO}_{3}^{-}\right)>5 \mathrm{~mm}$, total $\mathrm{Na}^{+}>2.0 \mathrm{~mm}$, and total $\mathrm{Cl}>4.0$ $\mathrm{mm}$ indicate poor quality water (Haby and Pennington, 1988).

Salinity can adversely affect plant water relations and growth because it leads to increasingly negative water potential $\left(\Psi_{w}\right)$ of xylem sap. Salinity can also adversely affect plant growth and metabolism because of the accumulation of potentially toxic concentrations of $\mathrm{Na}^{+}$and $\mathrm{Cl}$ - in the leaf mesophyll of salt-sensitive
\end{abstract}

Received for publication 20 Apr. 1992. Accepted for publication 3 Nov. 1992. Contribution from the Texas Agricultural Experiment Station (Paper no. TA30664) and supported in part by the Expanded Research Area Fund of the Experiment Station. We would like to thank Fincastle Nursery, La Rue, Texas, and Finch Nursery, Bailey, N.C., for the generous donation of the plants used in this study. The cost of publishing this paper was defrayed in part by the payment of page charges. Under postal regulations, this paper therefore must be hereby marked advertisement solely to indicate this fact.

${ }^{1}$ Assistant Research Scientist. Present address: Univ. of Arizona, Yuma Mesa Agricultural Center, Route I, Box 40M, Somerton, AZ 85350.

${ }^{2}$ Associate Professor of Horticulture. Present address: Washington State Univ.Coastal Washington Research and Extension Unit, Route I, Box 570 Pioneer Rd.. Long Beach, WA 98631.

${ }^{3}$ Professor of Horticultural Sciences. plants (Greenway and Munns, 1978). When salt sensitive plants are exposed to high levels of salt, particularly under conditions of poor root aeration, energy dependent processes that normally

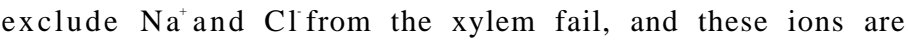
transported to the shoot (Drew and Dikumwin, 1985; Drew and Läuchli, 1985).

The damaging effects of poor quality water on growth of rabbiteye blueberry have been reported to be due to high concentrations of $\mathrm{Na}^{+}$(Haby et at., 1986). Field studies showed that weight gain of plants irrigated with well water containing $7.83 \mathrm{~mm}$ $\mathrm{Na}^{+}$was only $65 \%$ of that of plants irrigated with surface water containing $0.23 \mathrm{~mm} \mathrm{Na}^{+}$(Haby et al., 1986). Similarly, Bush et al. (1990) compared plants treated with pond and saline well water. After 5 months, 39\% of the plants irrigated with well water died, and after 12 months, the mortality was 60\%. For 'Tifblue' plants treated with $100 \mathrm{~mm} \mathrm{NaCl}$, shoot dry weight was only $57 \%$ of that of unsalinized controls (Wright et al., 1992). Additionally, growth of southern highbush blueberries appears to be just as adversely affected by $\mathrm{NaCl}$ as does that of rabbiteye blueberries (Wright et al., 1992).

Salinity stress also causes stomata1 closure and reduced gas exchange (Dinkelberg and Liidders, 1990; Downton et al., 1990;

Abbreviations: A, net assimilation: E, transpiration; $\mathrm{g}_{\mathrm{s}}$, stomatal conductance; PPFD, photosynthetic photon flux density; SAR, sodium adsorption ratio; $\Psi_{\boldsymbol{w}^{\prime}}$ xylem water potential. 
Drew et al., 1990; Seemann and Critchley, 1985). Salinity inhibits photosynthesis activity (Downton et al., 1990; Drew et al., 1990; Gupta and Berkowitz, 1987). possibly by reducing the activity of ribulose-1,5-bisphosphate carboxylase (Bongi and Loreto, 1989; Seemann and Critchley, 1985; Ziska et al., 1990). Reduced gas exchange may also be due to the lack of chlorophyll synthesis, as we have observed that field-grown plants show severe interveinal chlorosis when subjected to saline well water for long periods.

The benefits of $\mathrm{Ca}^{2+}$ application to salt-stressed plants is widely recognized. Improved shoot and/or root growth, as a result of $\mathrm{Ca}^{2+}$ application, occurred in bean Phaseolus vulgaris L. (LaHaye and Epstein, 1971), cotton Gossypium hirsutum L. (Cramer et al., 1988), maize Zea mays L. (Maas and Grieve, 1987), and Citrus sinensis (L.) Osb. (Ben-Hayyim and Kochba, 1982). Although reports of $\mathrm{Na}^{+} / \mathrm{Ca}^{2+}$ interactions affecting $\mathrm{A}$ are rare, there is evidence that $\mathrm{Na}^{+}$can compete with $\mathrm{Ca}^{2+}$ for the binding site on the $\mathrm{O}_{2}$ evolution reaction center in photosystem II (Waggoner et al., 1989).

Plants that have low leaf $\mathrm{Ca}^{2+}$ concentrations and thrive in soils low in $\mathrm{Ca}^{2+}$, such as Vaccinium species, are regarded as calcifuges (Hope-Simpson, 1938). Despite some research indicating that high soil $\mathrm{Ca}^{2+}$ is associated with poor blueberry growth and vigor (Austin et al., 1986; Ballinger et al., 1958), supplemental $\mathrm{Ca}^{2+}$ applications were found to improve the growth of 'Tifblue' and 'Brightwell' rabbiteye blueberries under medium and high $\mathrm{Na}_{2} \mathrm{SO}_{4}$ salinity (Wright et al., 1992). Therefore, the question arises as to whether $\mathrm{Ca}^{2+}$ application might improve growth of salinized blueberry by maintaining gas exchange and chlorophyll content.

The following experiments were designed to determine the effect of $\mathrm{Na}_{2} \mathrm{~S} \mathrm{O}_{4}$ and $\mathrm{NaCl}$ on gas exchange and chlorophyll content of rabbiteye and southern highbush blueberry plants. Sodium sulfate was applied to provide insight into the specific effect of $\mathrm{Na}^{+}$, since $\mathrm{SO}_{4}^{2-}$ is absorbed slowly by plants (Marschner, 1986) and is not known to damage blueberries. Salinization with $\mathrm{NaCl}$ was an alternative treatment designed to help understand the additional effect of $\mathrm{Cl}^{\circ}$ on gas exchange and chlorophyll content. Finally, plants were provided with supplemental $\mathrm{Ca}^{2+}$ to determine whether it exerted a protective effect on salinized blueberry plants.

\section{Materials and Methods}

$\mathrm{Na}_{2} \mathrm{SO}_{4}$ experiment. One-year-old, dormant 'Tifblue' rabbiteye blueberries were potted in sand and placed in a greenhouse on 15 Mar. 1988. Watering was by drip irrigation. Details of potting method and pretreatment irrigation were reported in Wright et al. (1992).

Treatments on 72 plants began 60 days later and consisted of 0 , 25 , or $100 \mathrm{mM} \mathrm{Na}^{+}\left(0,12.5\right.$, or $\left.50 \mathrm{mM} \mathrm{Na}_{2} \mathrm{SO}_{4}\right)$, arranged factorially with $0,1,3$, or $10 \mathrm{~mm} \mathrm{Ca}^{2+}$, and applied with the remaining essential elements in the nutrient solution. Because of the insolubility of $\mathrm{CaSO}_{4}$, only $70 \%$ of each $\mathrm{Ca}^{2+}$ treatment was $\mathrm{CaSO}_{4}$; the remainder was made up of $20 \% \mathrm{Ca}\left(\mathrm{NO}_{3}\right)_{2}$ and $10 \% \mathrm{CaCl}_{2}$. All treatments contained equal amounts of $\mathrm{NO}_{3}, \mathrm{NH}_{4}^{+}$, and $\mathrm{K}^{+}$. Plants received $\approx 400$ or $500 \mathrm{ml}$ of experimental solution daily by drip irrigation: this was sufficient for some solution to drain from the containers. Solution $\mathrm{pH}$ and electrical conductivity were recorded when solutions were formulated, and each time they were replenished. These values, along with solutioncomposition and sodium adsorption ratio (SAR), are found in Table 1.

Net assimilation, E, and $\mathrm{g}_{\mathrm{s}}$ were measured using an ADC portable system (Analytical Development Co., Hoddesdon, Herts., United Kingdom). Calculations used to obtain the above values were as described by von Caemmerer and Farquhar (1981) and
Parkinson and Allen (1985). Plants were transferred, within $\approx 3$ min, from the greenhouse to a nearby growth chamber, and gas exchange measurements were made immediately. All measurements were made between 1000 and 1500 HR CDT on the most recent fully expanded leaves. One leaf was measured on each of the 72 plants; thus six leaves were measured per treatment.

The ADC equipment allowed for continuous measurements on the target leaf, which was inserted into a $620 \mathrm{~mm}^{2}$ leaf cuvette. Preliminary measurements indicated that the light saturation point for blueberry was at a photosynthetic photon flux density (PPFD) of $\approx 700 \mathrm{umol} \cdot \mathrm{m}^{-2} \cdot \mathrm{s}^{-1}$; therefore, all subsequent measurements were taken at PPFD above the light saturation point, usually above $1000 \mathrm{~mol} \cdot \mathrm{m}^{-2} \cdot \mathrm{s}^{-1}$.

A photo incandescent flood lamp provided supplementary light when necessary. Air was drawn from outside the growth chamber and supplied to the leaf cuvette at $\approx 300 \mathrm{ml} \cdot \mathrm{min}^{-1 .}$ Air temperature within the growth chamber was at $27 \mathrm{C}$, and relative humidity was maintained at $\approx 50 \%$. Leaf temperature ranged from 22 to $32 \mathrm{C}$. External $\mathrm{CO}^{2}$ applied to the leaf was $\approx 340 \mu \mathrm{bar} \cdot \mathrm{bar}^{-1}$ (partial pressure). Leaves chosen for measurement were allowed to stabilize for $3 \mathrm{~min}$ before measurements were taken. Gas exchange was measured 21, 35, 49, and 63 days following initiation of $\mathrm{Na}_{2} \mathrm{~S} \mathrm{O}_{4}$ and $\mathrm{Ca}^{2+}$ treatments.

Predawn $\Psi$ was measured 62 days from the start of salt treatments, between 0100 and $0600 \mathrm{HR}$, using a pressure chamber (Soil Moisture Corp., Santa Barbara, Calif.). $\boldsymbol{\Psi}_{\boldsymbol{w}}$ was determined on two fully expanded leaves to give two sub samples per plant.

Leaf chlorophyll was determined using a SPAD-501 portable chlorophyll meter (Minolta Corp., Ramsey, N.J.), which nondestructively estimates chlorophyll $\mathrm{a}$ and $\mathrm{b}$ concentration in relative units. Four leaves were measured per plant. Leaves with incremental chlorophyll levels (determined by SPAD-501 readings) were then harvested to construct a standard curve for quantification of chlorophyll content. Five $1.0 \mathrm{~cm}^{2}$ disks were removed from each leaf. Chlorophyll was extracted using $\mathrm{N}, \mathrm{N}$-dimethylformamide, and chlorophyll concentration, and each disk was calculated from the equation developed by Moran (1982): Extractable chlorophyll $\left(\mathrm{mg} \cdot \mathrm{liter}^{-1}\right)=\left(20.27 \times \mathrm{A}_{647}\right)+\left(7.04 \times \mathrm{A}_{664}\right)$, where $\mathrm{A}_{647}$ and $\mathrm{A}_{664}$ refer, respectively, to adsorbance at wavelengths of 647 and $664 \eta \mathrm{m}$ measured in a spectrophotometer. Adsorbance of leaf extracts was measured using a Varian DMS-100 UV Visible Spectrophotometer (Varian Techtron, Mulgrave, Victoria, Australia). Chlorophyll concentration was expressed on a leaf weight basis, and the standard curve was calculated using the regression equation: Total chlorophyll $\left(\mathrm{mg} \cdot \mathrm{g}^{-1}\right.$ fresh weight $)=-722.182+$ $(71.81 \times \mathrm{SPAD}$ reading $) R^{2}=0.85$.

The design was a randomized complete block. Experiments were $4\left(\mathrm{Ca}^{2+}\right.$ levels $) \times 3\left(\mathrm{Na}^{+}\right.$levels $)$factorial with six single-plant replications. Data were analyzed using the General Linear Model procedure (PROC GLM) of the Statistical Analysis Service (SAS) software package (SAS, Cary, N.C.).

$\mathrm{NaCl}$ experiment. Dormant, bare-root 'Tifblue' rabbiteye blueberries and 'Sharpblue' southern highbush blueberries wereplanted in sand on 15 Mar. 1989, placed in the greenhouse, and watered by drip irrigation. The potting method and pretreatment irrigation regime is reported in Wright et al. (1992).

Plants were maintained with the complete nutrient solution until 15 May 1989, when treatments commenced. All plants received $\mathrm{NaCl}$, rather than $\mathrm{Na}_{2} \mathrm{SO}_{4}$, as the $\mathrm{Na}^{+}$source in 1989 , but otherwise the compositions of the 12 nutrient solutions were no different from those of 1988. Solution $\mathrm{pH}$ and electrical conductivity were again measured when the solutions were formulated and replenished (Table 1). 'Sharpblue' plants were only treated with 


\begin{tabular}{|c|c|c|c|c|c|c|c|c|c|c|c|c|}
\hline \multicolumn{9}{|c|}{$(\mathrm{mM})$} & \multicolumn{2}{|c|}{$\mathrm{pH}^{\mathrm{x}}$} & \multicolumn{2}{|c|}{ E.C. } \\
\hline Total $\mathrm{Na}^{+y}$ & Total $\mathrm{Ca}^{2+}$ & $\mathrm{CaSO}_{4}$ & $\mathrm{Ca}\left(\mathrm{NO}_{3}\right)_{2}$ & $\mathrm{CaCl}_{2}$ & $\mathrm{KNO}_{3}$ & $\left(\mathrm{NH}_{4}\right)_{2} \mathrm{SO}_{4}$ & $\mathrm{~K}_{2} \mathrm{SO}_{4}$ & SAR & $\mathrm{Na}_{2} \mathrm{SO}_{4}$ & $\mathrm{NaCl}$ & $\mathrm{Na}_{2} \mathrm{SO}_{4}$ & $\mathrm{NaCl}$ \\
\hline & & & & & & & & & & & \multicolumn{2}{|c|}{$\left(d S \cdot m^{-1}\right)$} \\
\hline 0 & 0 & 0.0 & 0.0 & 0.0 & 4.0 & 4.0 & 0.0 & 0.0 & 6.1 & 5.4 & 1.22 & 1.18 \\
\hline 0 & 1 & 0.7 & 0.2 & 0.1 & 3.6 & 4.0 & 0.4 & 0.0 & 5.4 & 5.3 & 1.30 & 1.38 \\
\hline 0 & 3 & 2.1 & 0.6 & 0.3 & 2.8 & 4.0 & 1.2 & 0.0 & 5.2 & 5.0 & 1.62 & 1.81 \\
\hline 0 & 10 & 7.0 & 2.0 & 1.0 & 0.0 & 4.0 & 4.0 & 0.0 & 5.1 & 5.1 & 2.37 & 2.49 \\
\hline 25 & 0 & 0.0 & 0.0 & 0.0 & 4.0 & 4.0 & 0.0 & 31.0 & 5.5 & 6.4 & 3.23 & 3.80 \\
\hline 25 & 1 & 0.7 & 0.2 & 0.1 & 3.6 & 4.0 & 0.4 & 19.4 & 5.6 & 5.0 & 3.34 & 3.75 \\
\hline 25 & 3 & 2.1 & 0.6 & 0.3 & 2.8 & 4.0 & 1.2 & 13.0 & 6.1 & 5.1 & 3.72 & 3.80 \\
\hline 25 & 10 & 7.0 & 2.0 & 1.0 & 0.0 & 4.0 & 4.0 & 7.6 & 6.0 & 4.9 & 4.00 & 4.53 \\
\hline 100 & 0 & 0.0 & 0.0 & 0.0 & 4.0 & 4.0 & 0.0 & 124.0 & 6.7 & 5.3 & 8.87 & 8.80 \\
\hline 100 & 1 & 0.7 & 0.2 & 0.1 & 3.6 & 4.0 & 0.4 & 77.8 & 6.0 & 5.4 & 8.08 & 9.35 \\
\hline 100 & 3 & 2.1 & 0.6 & 0.3 & 2.8 & 4.0 & 1.2 & 52.3 & 6.2 & 5.0 & 8.92 & 9.55 \\
\hline 100 & 10 & 7.0 & 2.0 & 1.0 & 0.0 & 4.0 & 4.0 & 30.6 & 5.9 & 5.1 & 8.72 & 8.48 \\
\hline
\end{tabular}

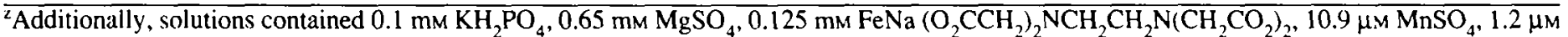
$\mathrm{H}_{3} \mathrm{BO}_{3}, 0.2 \mu \mathrm{M} \mathrm{CuSO}_{4}, 0.076 \mu_{\mathrm{M}} \mathrm{ZnSO}_{4}$, and $15 \mu \mathrm{M}\left(\mathrm{NH}_{4}\right)_{6} \mathrm{Mo}_{7} \mathrm{O}_{24} . \mathrm{SAR}=$ sodium adsorption ratio.

YTotal $\mathrm{Na}^{+}$as $\mathrm{Na}_{2} \mathrm{SO}_{4}$ or as $\mathrm{NaCl}$.

${ }^{\mathrm{x}} \mathrm{pH}$ and E.C. values are means of at least three replications.

those solutions containing 0 and $10 \mathrm{~mm} \mathrm{Ca}^{2+}$ because sufficient plants were not available to test all $\mathrm{Ca}^{2+}$ levels.

Gas exchange and $\Psi_{w}$ measurement protocol was the same as that of the 1988 experiment. Gas exchange was measured immediately before salt treatment (time $=0$ ) and 7, 21, 35, 49, and 63 days after treatment. Xylem water potential was measured just 30 days after the salt treatments commenced because leaf necrosis on high $\mathrm{NaCl}$ treatments was becoming apparent.

Leaf chlorophyll concentration was again determined using the SPAD-501 portable chlorophyll meter as described above, and was expressed on a leaf weight basis.

The design and data analysis were the same as described previously. The experiment involving 'Sharpblue' was a $2 \times 3$ factorial with four replications for a total of 24 plants

\section{Results}

Blueberry cultivars responded differently to $\mathrm{Na}_{2} \mathrm{SO}_{4}$ and $\mathrm{NaCl}$ treatment, so that data could not be averaged over both cultivars. The principal effects of salinity on gas exchange are described below (Tables 2 to 5), and interactions between salt concentration and $\mathrm{Ca}^{2+}$ are given graphically (Figs. 1 to 6).

$\mathrm{Na}_{2} \mathrm{SO}_{4}$ experiment. Stomatal conductance ( $\mathrm{g}_{\mathrm{s}}$ ) decreased linearly with increasing $\mathrm{Na}_{2} \mathrm{SO}_{4}$ concentrations in the external solution and with time of exposure to salinity (Table 2). The $\mathrm{Ca}^{2+} \times \mathrm{Na}^{+}$ treatment interaction also led to significant differences in $\mathrm{g}_{\mathrm{s}}$ (Fig. 1). For unsalinized plants, $\mathrm{g}_{\mathrm{s}}$ was not affected by $\mathrm{Ca}^{2+}$ treatment until day 49, when plants supplied with $10 \mathrm{~mm} \mathrm{Ca}^{2+}$ had significantly lower $\mathrm{g}$, and at 63 days when $\mathrm{g}_{\mathrm{s}}$ of those same plants was halved. In contrast, with $25 \mathrm{mM} \mathrm{Na}^{+}$as $\mathrm{Na}_{2} \mathrm{~S} \mathrm{O}_{4}, \mathrm{Ca}^{2+}$ addition did not reduce $\mathrm{g}$,. For plants treated with $100 \mathrm{mM} \mathrm{Na}^{+}, \mathrm{g}_{\mathrm{s}}$ was 1.5 to 2.5 times higher with $1 \mathrm{mM} \mathrm{Ca}^{2+}$ addition, with somewhat smaller increases in $\mathrm{g}_{\mathrm{s}}$ with 3 and $10 \mathrm{mM} \mathrm{Ca} \mathrm{a}^{2+}$, compared to plants not supplied with $\mathrm{Ca}^{2+}$.

Changes in leaf transpiration rate (E) in response to $\mathrm{N}_{\mathrm{a}} 2 \mathrm{SO}_{4}$ and $\mathrm{Ca}^{2+}$ were very similar to the response of $\mathrm{g}_{\mathrm{s}}$ (Table 2 ).

Net assimilation rate (A) was also reduced linearly as $\mathrm{Na}^{+}$in the external solution increased (Table 2). For unsalinized plants, $\mathrm{Ca}^{2+}$ did not lead to improved assimilation (Fig. 2A). After 63 days, unsalinized plants treated with $10 \mathrm{~mm} \mathrm{Ca}^{2+}$ exhibited a $50 \%$ drop in A compared to plants not receiving $\mathrm{Ca}^{2+}$. However, $\mathrm{Ca}$ treat- ments were beneficial to salinized plants (Fig. 2B and 2C). With $12.5 \mathrm{~mm} \mathrm{Na}^{+}$, plants receiving supplemental $\mathrm{Ca}^{2+}$ had significantly higher A after 35 days of treatment. For plants supplied with $50 \mathrm{~mm}$ $\mathrm{Na}^{+}$, A was usually significantly higher when plants were supplied with $\mathrm{Ca}^{2+}$. For example, after 35 days of treatment, A of plants supplied with $1 \mathrm{mM} \mathrm{Ca}^{2+}$ was 1.5 to 2 times higherthan that of plants not treated with $\mathrm{Ca}^{2+}$.

Table 2. Influence of $\mathrm{Na}_{2} \mathrm{SO}_{4}$ and $\mathrm{Ca}^{2+}$ treatments on stomatal conductance $\left(\mathrm{g}_{\mathrm{s}}\right)$, transpiration (E), and net assimilation (A) of 'Tifblue' rabbiteye blueberry plants.

\begin{tabular}{|c|c|c|c|c|}
\hline \multicolumn{2}{|c|}{$\begin{array}{l}\text { Treatment } \\
\text { (mM) }\end{array}$} & \multirow[t]{2}{*}{$\begin{array}{c}\mathrm{g}_{\mathrm{s}} \\
\left(\mathrm{mmol} \cdot \mathrm{m}^{-2} \cdot \mathrm{s}^{-1}\right)\end{array}$} & \multirow[t]{2}{*}{$\begin{array}{c}E \\
\left(\mathrm{~mol} \cdot \mathrm{m}^{-2} \cdot \mathrm{s}^{-1}\right)\end{array}$} & \multirow[t]{2}{*}{$\begin{array}{c}\mathrm{A} \\
\left(\mu \mathrm{mol} \cdot \mathrm{m}^{-2} \cdot \mathrm{s}^{1}\right)\end{array}$} \\
\hline $\mathrm{Na}^{+}$ & $\mathrm{Ca}^{2+}$ & & & \\
\hline 0 & 0 & 0.213 & 4.96 & 9.00 \\
\hline 0 & 1 & 0.187 & 4.56 & 8.47 \\
\hline 0 & 3 & 0.207 & 4.73 & 8.79 \\
\hline 0 & 10 & 0.154 & 3.95 & 7.67 \\
\hline 25 & 0 & 0.148 & 3.90 & 6.87 \\
\hline 25 & 1 & 0.165 & 4.25 & 8.16 \\
\hline 25 & 3 & 0.180 & 4.53 & 7.65 \\
\hline 25 & 10 & 0.184 & 4.61 & 8.95 \\
\hline 100 & 0 & 0.066 & 2.05 & 3.80 \\
\hline 100 & 1 & 0.125 & 3.57 & 6.55 \\
\hline 100 & 3 & 0.090 & 2.93 & 6.14 \\
\hline 100 & 10 & 0.103 & 3.13 & 6.68 \\
\hline
\end{tabular}

$\begin{array}{lccc}\begin{array}{l}\text { Source } \\ \mathrm{Ca}^{2+}\end{array} & & & \\ \quad \text { Linear } & \mathrm{NS} & 0.0441 & 0.0249 \\ \quad \text { Quadratic } & \mathrm{NS} & \mathrm{NS} & 0.0822 \\ \mathrm{Na}^{+} & 0.0001 & 0.0451 & \mathrm{NS} \\ \quad \text { Linear } & 0.0001 & 0.0001 & 0.0001 \\ \text { Timey } & 0.0001 & 0.0001 & 0.0001 \\ \quad \text { Linear } & 0.0001 & 0.0001 & 0.0001 \\ \quad \text { Quadratic } & 0.0001 & 0.0001 & 0.0593 \\ \mathrm{Na}^{+} \times \text {time } & 0.0011 & 0.0002 & 0.0001 \\ \mathrm{Ca}^{2+} \times \mathrm{Na}^{+} & 0.0029 & 0.0007 & 0.0092 \\ \end{array}$

${ }^{2}$ Probability of a significant $\mathrm{F}$ value, NS = nonsignificant. Both quadratic and cubic $\mathrm{Na}^{+}$contrasts were nonsignificant.

y Days after salt application (treatment duration). 


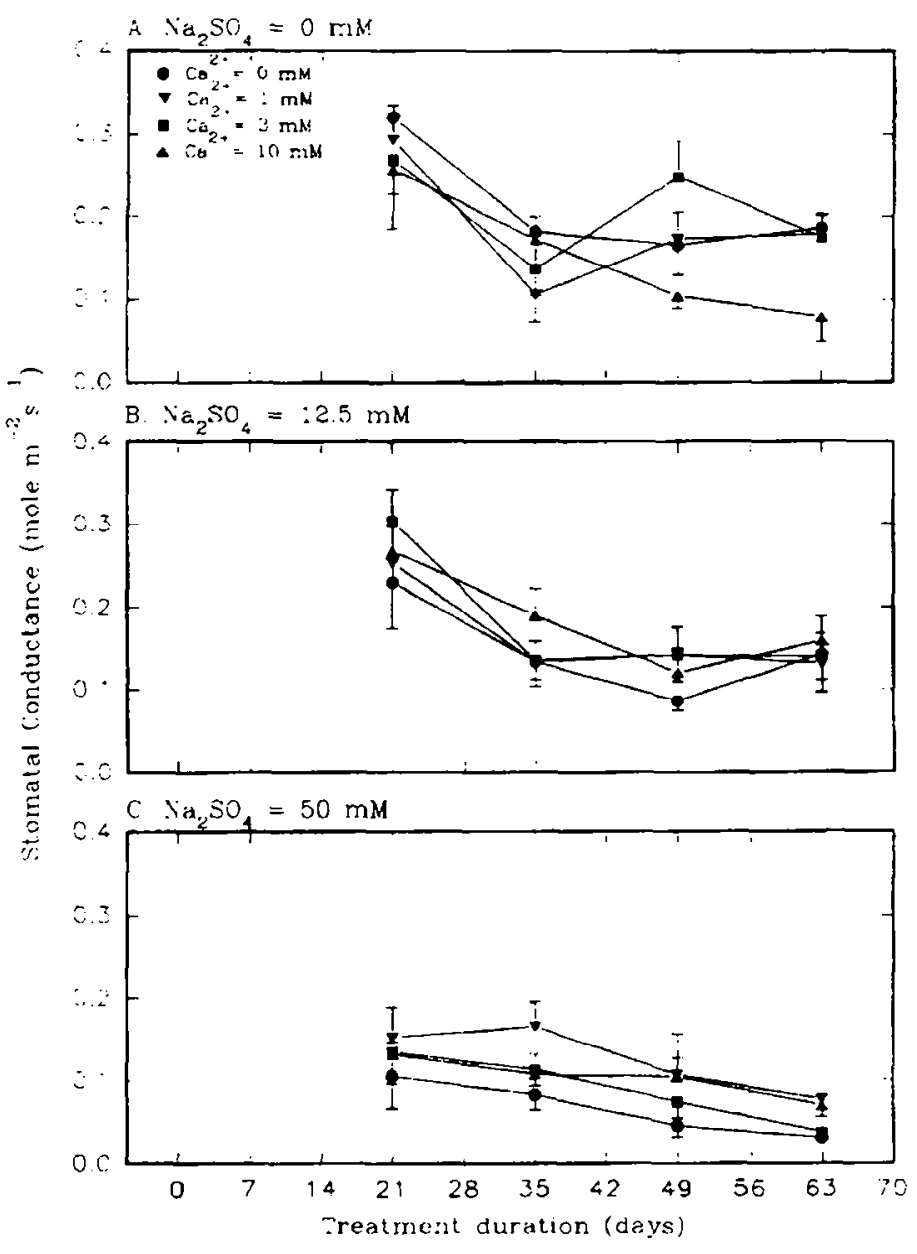

Fig. 1. Stomatal conductance of 'Tifblue' rabbiteyc blueberries treated with $\mathrm{Na}_{2} \mathrm{SO}_{4}$ and $\mathrm{Ca}^{2+}$. Vertical bars indicate $\mathrm{SE}$.

Xylem water potential $\left(\Psi_{w}\right)$ also declined in response to increasing $\mathrm{Na}^{+}$in the external solution (Table 3). For unsalinized plants and those plants treated with $25 \mathrm{~mm} \mathrm{Na}$ as $\mathrm{Na}_{2} \mathrm{SO}_{4}, \mathrm{Ca}^{2+}$ treatments did not improve $\Psi$.However, for plants treated with $100 \mathrm{~mm} \mathrm{Na}{ }^{+}, \Psi_{\text {was }}$ at least $15 \%$ higherwhen any level of $\mathrm{Ca}^{2+}$ was applied. Leaf chlorophyll concentration increased with time (Fig. 3 ). Calcium concentration did not consistently affect leaf chlorophyll concentration of unsalinized plants or plants treated with 25 $\mathrm{mM} \mathrm{Na}^{+}$as $\mathrm{Na}_{2} \mathrm{SO}_{4}$. However, for plants supplied with $100 \mathrm{mM} \mathrm{Na}^{+}$, $\mathrm{Ca}^{2+}$ supplementation led to visibly higher leaf chlorophyll concentrations after 42 days of treatment.

$\mathrm{NaCl}$ experiment. Stomata1 conductance of 'Tifblue' plants decreased linearly with increasing concentrations and duration of $\mathrm{Na}^{+}$treatment (Table 4). After 63 days, $\mathrm{g}_{\mathrm{s}}$ of 'Tifblue' plants subject to $100 \mathrm{~mm} \mathrm{Na}$ as $\mathrm{NaCl}$ was only $10 \%$ of unsalinized controls (Fig. 4). The $\mathrm{g}_{\mathrm{s}}$ of unsalinized controls was unaffected by $\mathrm{Ca}^{2+}$ treatment. Similarly, $\mathrm{Ca}^{2+}$ had little apparent influence on $\mathrm{g}$ s of plants subject to $25 \mathrm{~mm} \mathrm{Na}^{+}$until day 49, after which time, plants supplied with $1 \mathrm{mM} \mathrm{Ca}^{2+}$ had significantly higher $\mathrm{g}_{\mathrm{s}}$ than plants not given $\mathrm{Ca}^{2+}$ For plants subjected to $100 \mathrm{mM} \mathrm{N} \mathrm{a}^{+}$treatment, $\mathrm{g}_{\mathrm{s}}$ decreased to a very low value $\left(0.01\right.$ to $\left.0.02 \mathrm{~mol} \cdot \mathrm{m}^{-2} \cdot \mathrm{s}^{-1}\right)$ by day 7 . At day 35 and 49, $\mathrm{g}_{\mathrm{s}}$ was significantly higher in plants given additional $\mathrm{Ca}^{2+}$, which paralleled a small rise in $\mathrm{A}$.

Effects of $\mathrm{NaCl}$ salinity and $\mathrm{Ca}^{2+}$ on 'Tifblue' $\mathrm{E}$ were similar to the effects on $\mathrm{g}_{\mathrm{s}}$ (Table 4).

Net assimilation of 'Tifblue' plants decreased linearly as the concentration of $\mathrm{NaCl}$ in the external solution increased (Table 4).

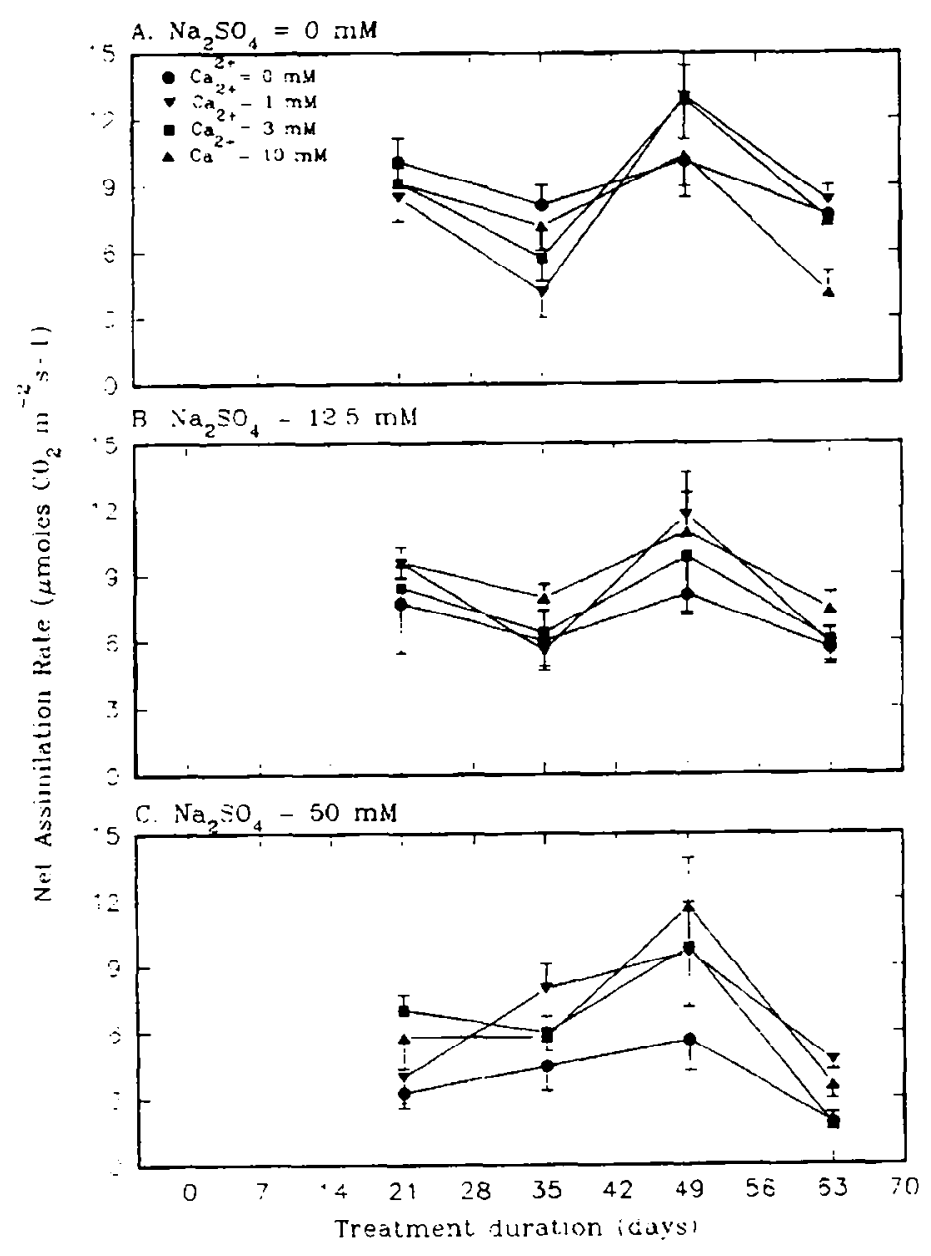

Fig. 2. Net assimilation rate of 'T'ifblue' rabbiteye blueberries treated with $\mathrm{Na}_{2} \mathrm{SO}_{4}$ and $\mathrm{Ca}^{2+}$. Vertical bars indicate $\mathrm{sE}$.

Table 3. Influence of $\mathrm{Na}_{2} \mathrm{SO}_{4}$ or $\mathrm{NaCl}$ and $\mathrm{Ca}^{2+}$ treatments on xylem water polential $\left(\Psi_{w}\right)$ of rabbiteye and southern highbush blucberry plants.

\begin{tabular}{|c|c|c|c|c|}
\hline \multirow{2}{*}{\multicolumn{2}{|c|}{$\begin{array}{l}\text { Treatment } \\
\quad(\mathrm{mM})\end{array}$}} & \multicolumn{3}{|c|}{$\Psi_{w}(\mathrm{MPa})$} \\
\hline & & \multirow[t]{2}{*}{$\begin{array}{l}\mathrm{Na}_{2} \mathrm{SO}_{4} \text {, } \\
\text { 'Tifblue' }\end{array}$} & \multirow[t]{2}{*}{$\begin{array}{c}\mathrm{NaCl} \\
\text { 'Tifblue' }\end{array}$} & \multirow[t]{2}{*}{$\begin{array}{c}\mathrm{NaCl} \\
\text { 'Sharpblue }\end{array}$} \\
\hline$\overline{\mathrm{Na}}$ & $\mathrm{Ca}^{2+}$ & & & \\
\hline 0 & 0 & -0.226 & -0.187 & -0.190 \\
\hline 0 & 1 & -0.300 & -0.178 & -- \\
\hline 0 & 3 & -0.282 & -0.178 & --- \\
\hline 0 & 10 & -0.320 & -0.190 & -0.242 \\
\hline 25 & 0 & -0.365 & -0.298 & -0.360 \\
\hline 25 & 1 & -0.446 & -0.236 & --- \\
\hline 25 & 3 & -0.450 & -0.171 & --- \\
\hline 25 & 10 & -0.408 & -0.241 & -0.357 \\
\hline 100 & 0 & -0.611 & -0.398 & -0.543 \\
\hline 100 & 1 & -0.484 & -0.416 & -- \\
\hline 100 & 3 & -0.520 & -0.385 & --- \\
\hline 100 & 10 & -0.520 & -0.371 & -0.540 \\
\hline
\end{tabular}

$\begin{array}{lccc}\begin{array}{l}\text { Source } \\ \mathrm{Ca}^{2+}\end{array} & \mathrm{NS} & 0.0144 & \mathrm{NS} \\ \mathrm{Na}^{+} & 0.0001 & 0.0001 & 0.0001 \\ \quad \text { Linear } & 0.0001 & 0.0001 & 0.0001 \\ \mathrm{Ca}^{2+} \times \mathrm{Na}^{+} & 0.0020 & 0.0207 & \text { NS }\end{array}$

$\overline{{ }^{2} \text { Probability of a significant } \mathrm{F} \text { value, } \mathrm{NS}=\text { nonsignificant. Linear } \overline{\mathrm{Ca}^{2+}} \text { was }}$ nonsignificant. 


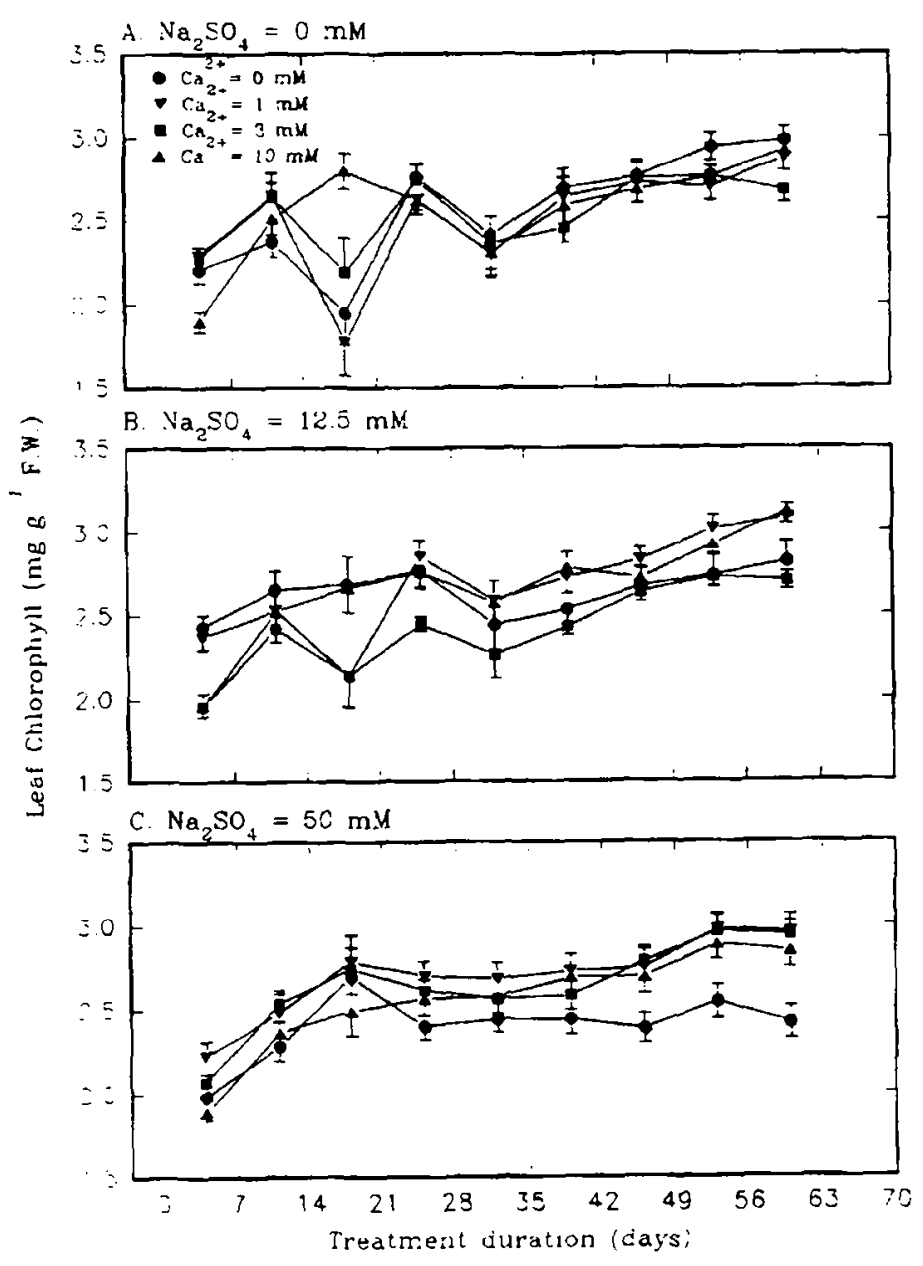

Fig. 3. Leaf chlorophyll concentration of 'Tifblue' rabbiteye blueberries treated with $\mathrm{Na}_{2} \mathrm{SO}_{4}$ and $\mathrm{Ca}^{2+}$. Vertical bars indicate $\mathrm{SE}$.

For plants treated with $100 \mathrm{mM} \mathrm{Na}^{+}$, A was only $10 \%$ to $20 \%$ of that of unsalinized controls after 63 days of treatment. There was only slight ameliorative effect of $\mathrm{Ca}^{2+}$ when $\mathrm{NaCl}$ was applied. For unsalinized 'Tifblue' plants, $\mathrm{Ca}^{2+}$ had no influence on $\mathrm{A}$, while for plants receiving $25 \mathrm{~mm} \mathrm{NaCl}, \mathrm{Ca}^{2+}$ supplementation had improved net $\mathrm{A}$ only at 49 days after treatment initiation (Fig. 5). For plants treated with $100 \mathrm{mM} \mathrm{NaCl}, \mathrm{Ca}^{2+}$ treatments did not improve A, which dropped within the first 7 days of treatment, and rose only slightly thereafter.

Xylem water potential $\left(\Psi_{w}\right)$ of 'Tifblue' plants also decreased linearly with increasing $\mathrm{NaCl}^{w}$ (Table 3). For plants salinized with $100 \mathrm{mM} \mathrm{Na}^{+}, \Psi_{w}$ decreased to about $-0.39 \mathrm{MPa}$. Calcium treatments were most effective in plants salinized with $25 \mathrm{mM} \mathrm{NaCl}$, where $3 \mathrm{mM} \mathrm{Ca}^{2+}$ led to a higher $\Psi_{w}(-0.17 \mathrm{MPa})$ than in the controls (-0.29 MPa). Calcium treatments did not influence $\boldsymbol{\Psi}_{\boldsymbol{w}}$ of plants under 0 or $100 \mathrm{~mm} \mathrm{NaCl}$ salinity.

Leaf chlorophyll of 'Tifblue' plants was seldom influenced by $\mathrm{Ca}^{2+}$ and $\mathrm{NaCl}$ treatment (data not shown). For unsalinized plants, $\mathrm{Ca}^{2+}$ treatments had no consistent effect on leaf chlorophyll concentration. With $25 \mathrm{mM} \mathrm{Na}^{+}$as $\mathrm{NaCl}$, the highest chlorophyll concentration was in the leaves of plants supplied with $3 \mathrm{mM} \mathrm{Ca}^{2+}$, while at $100 \mathrm{mM} \mathrm{NaCl}$ salinity those that received $1 \mathrm{mM} \mathrm{Ca}^{2+}$ additions often had the most chlorophyll. In no case did we observe severe chlorosis resembling that which we have observed in fieldgrown blueberries irrigated with saline well water.

Stomatal conductance, A, and E of 'Sharpblue' southern highbush plants were severely inhibited by $\mathrm{NaCl}$ (Table 5). Calcium had no ameliorative effect of $\mathrm{NaCl}$-induced reductions in gas exchange. In contrast, both $\mathrm{Ca}^{2+}$ and $\mathrm{NaCl}$ treatments had significant influences on leaf chlorophyll concentration (Fig. 6). For unsalinized controls, plants supplied with $10 \mathrm{mM} \mathrm{Ca}^{2+}$ had higher concentrations than plants without added $\mathrm{Ca}^{2+}$. For plants supplied with $25 \mathrm{mM} \mathrm{NaCl}, \mathrm{Ca}^{2+}$ treatment had little influence on leaf chlorophyll concentration. After 35 days of $100 \mathrm{mM} \mathrm{NaCl}$ salinity, plants given $10 \mathrm{mM} \mathrm{Ca}^{2+}$ had lower leaf chlorophyll concentrations, compared to plants given no additional $\mathrm{Ca}^{2+}$. However, this reduction was more due to extensive leaf necrosis in the $10 \mathrm{mM} \mathrm{Ca}^{2+}$ treated plants than to leaf chlorosis.

\section{Discussion}

High (100 mM) $\mathrm{Na}^{+}$supplied as $\mathrm{Na}_{2} \mathrm{SO}_{4}$ or $\mathrm{NaCl}$ to 'Tifblue' or 'Sharpblue' blueberries reduced $\mathrm{g}_{\mathrm{s}}$ (Tables 2, 4, and 5). After 21 days of $100 \mathrm{mM} \mathrm{NaCl}$ salinization, $\mathrm{g}_{\mathrm{s}}$ decreased by $90 \%$. In contrast, $\mathrm{g}_{\mathrm{s}}$ of cucumber (Cucumis sativus L.) dropped by only $\approx 50 \%$ after 28 days of $50 \mathrm{~mm} \mathrm{NaCl}$ salinization (Drew et al., 1990). Also, Bongi and Loreto (1989) noted that $\mathrm{g}_{\mathrm{s}}$ of olive (Olea europaea L.) dropped significantly in the presence of $250 \mathrm{mM}$ $\mathrm{NaCl}$ (dilute seawater). In our study, reduction in $\mathrm{g}_{\mathrm{s}}$ was also dependent on the $\mathrm{Na}^{+}$salt applied. For example, after 63 days, conductance of plants subject to $100 \mathrm{mM} \mathrm{Na}{ }^{+}$as $\mathrm{Na}_{2} \mathrm{SO}_{4}$ was still $35 \%$ of that of unsalinized controls.

One factor leading to stomatal closure in blueberry under high $\mathrm{Na}^{+}$concentrations may be the lower $\Psi_{w}$ (Table 3). Regardless of $\mathrm{Na}^{+}$source, $\Psi_{w}$ decreased as $\mathrm{Na}+$ concentration in the external solution increased. A loss of leaf turgor could cause stomatal closure. In other studies, the rise in leaf ABA concentration and an associated closure of stomates has been well documented (Zeevart

Table 4. Influence of $\mathrm{NaCl}$ and $\mathrm{Ca}^{2+}$ treatments on stomatal conductance $\left(\mathrm{g}_{\mathrm{s}}\right)$. transpiration $(\mathrm{E})$, and net assimilation $(\mathrm{A})$ of 'Tifblue' rabbiteye blueberry plants.

\begin{tabular}{|c|c|c|c|c|}
\hline \multicolumn{2}{|c|}{$\begin{array}{l}\text { Treatment } \\
\text { (mM) }\end{array}$} & \multirow[t]{2}{*}{$\begin{array}{c}\mathrm{g}_{\mathrm{s}} \\
\left(\mathrm{mol} \cdot \mathrm{m}^{-2} \cdot \mathrm{s}^{-1}\right)\end{array}$} & \multirow[t]{2}{*}{$\begin{array}{c}E \\
\left(\mathrm{mmol} \cdot \mathrm{m}^{-2} \cdot \mathrm{s}^{-1}\right)\end{array}$} & \multirow[t]{2}{*}{$\begin{array}{c}\text { A } \\
\left(\mu \mathrm{mol} \cdot \mathrm{m}^{-2} \cdot \mathrm{s}^{-1}\right)\end{array}$} \\
\hline $\mathrm{Na}^{+}$ & $\mathrm{Ca}^{2+}$ & & & \\
\hline 0 & 0 & 0.205 & 4.34 & 7.77 \\
\hline 0 & 1 & 0.194 & 4.24 & 4.24 \\
\hline 0 & 3 & 0.161 & 3.75 & 5.92 \\
\hline 0 & 10 & 0.167 & 3.90 & 6.52 \\
\hline 25 & 0 & 0.101 & 2.53 & 4.06 \\
\hline 25 & 1 & 0.105 & 2.88 & 5.08 \\
\hline 25 & 3 & 0.125 & 3.27 & 5.62 \\
\hline 25 & 10 & 0.105 & 2.93 & 5.01 \\
\hline 100 & 0 & 0.025 & 0.70 & 1.33 \\
\hline 100 & 1 & 0.035 & 1.15 & 1.91 \\
\hline 100 & 3 & 0.039 & 1.24 & 2.28 \\
\hline 100 & 10 & 0.057 & 0.70 & 2.18 \\
\hline \multicolumn{5}{|c|}{ Source ${ }^{z}$} \\
\hline $\mathrm{Ca}^{2+}$ & & NS & NS & NS \\
\hline $\mathrm{Na}^{+}$ & & 0.0001 & 0.0001 & 0.0001 \\
\hline & near & 0.0001 & 0.0001 & 0.0001 \\
\hline Time & & 0.0001 & 0.0001 & 0.0001 \\
\hline & near & NS & 0.0001 & 0.0001 \\
\hline & adratic & 0.0001 & 0.0001 & 0.0001 \\
\hline $\mathrm{Na}^{+}>$ & time & 0.0001 & 0.0001 & 0.0001 \\
\hline $\mathrm{Ca}^{2+}$ & $\mathrm{Na}^{+}$ & 0.0001 & 0.0826 & NS \\
\hline
\end{tabular}

${ }^{2}$ Probability of a significant $\mathrm{F}$ value, NS = nonsignificant.

${ }^{\mathrm{y}}$ Days after salt application (treatment duration). 


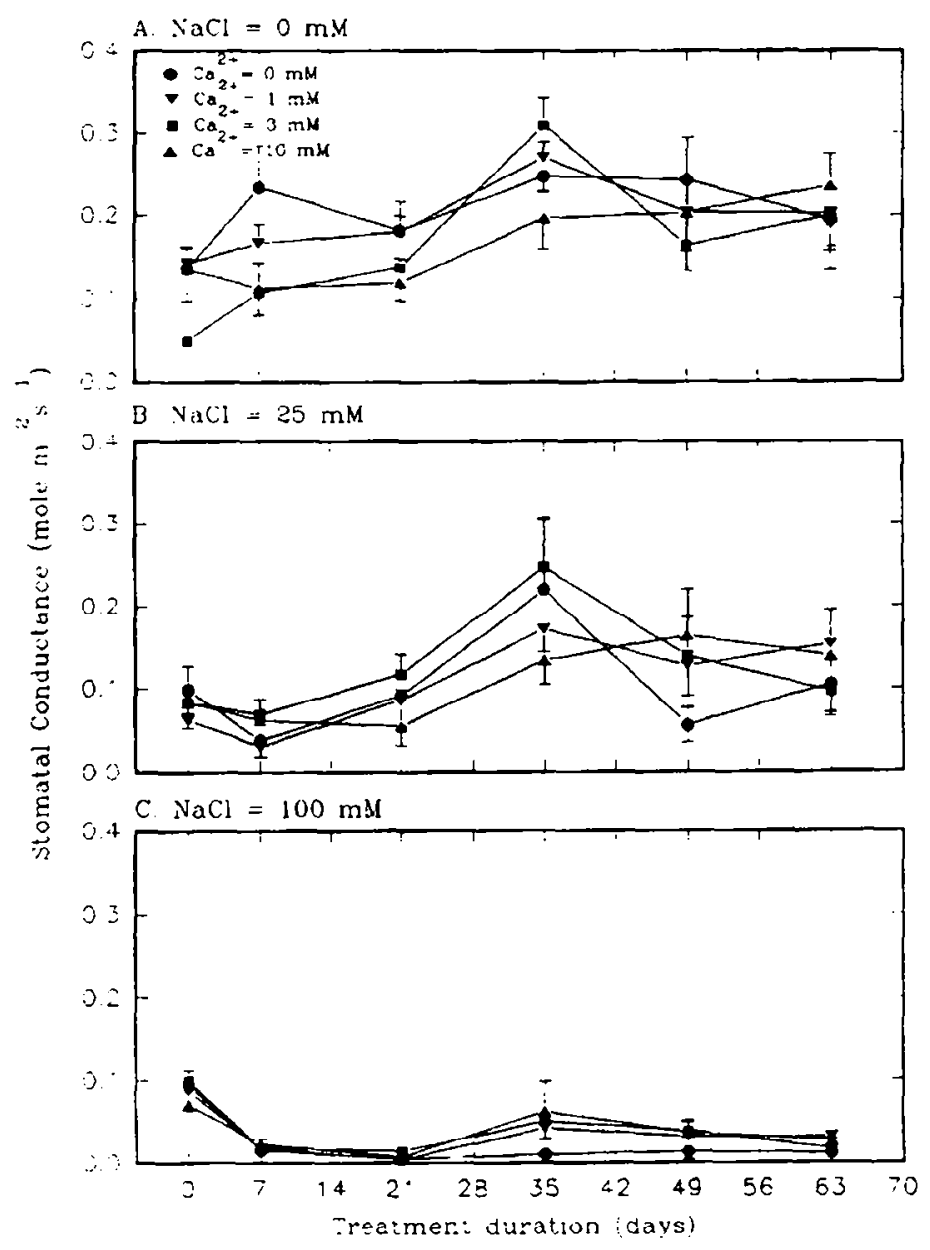

Fig. 4. Stomatal conductance of 'Tifblue' rabbiteye blueberries treated with $\mathrm{NaCl}$ and $\mathrm{Ca}^{2+}$. Vertical bars indicate SE.

and Creelman, 1988). A further source of ABA to leaves may be the roots in contact with medium of low water potential (Zhang et al., 1987).

Like $\mathrm{g}_{s}$, A also decreased as salt concentrations in the irrigation solution Increased (Figs. 2 and 5). Stomatal closure often limits net A, but that is not always the case. With salinized cucumber (Drew et al., 1990). bell pepper ( Capsicum annuum L.) (Bethke and Drew, 1992), rice ( Oryza sativa L.) (Yeo et al., 1985), and Phaseolus vulgaris L. (Seemann and Critchley, 1985), partial closure of stomata did not restrict $\mathrm{CO}_{2}$ entry into the leaf enough to reduce internal $\mathrm{CO}_{2}$ concentration. Inhibition of $\mathrm{A}$ was attributed in all these cases to do damage to the photosynthetic apparatus of the chloroplasts, and such damage is possibly a major factor in the decreases in A found in our studies.

Calcium deficiency may also contribute to impaired net $\mathrm{A}$ under high salinity treatments. Leaf $\mathrm{Ca}^{2+}$ levels of plants treated with high levels of $\mathrm{Na}_{2} \mathrm{~S} \mathrm{O}_{4}$ and $\mathrm{NaCl}$ were $0.11 \%$ and $0.15 \%$. respectively (Wright et-al., unpublished data). These concentrations border on the deficient (Patten, 1988). Leaf $\mathrm{Na}^{+}$concentrations of these plants were $0.14 \%$ and $1.1 \%$, respectively. Lynch and Läuchli (1985) suggest that high salinity reduces $\mathrm{Ca}^{2+}$ transport by interfering with active loading of $\mathrm{Ca}^{2+}$ into xylem vessels. Sodium would then compete with fewer $\mathrm{Ca}^{2+}$ ions for a binding site on the $\mathrm{O}_{2}$ evolution reaction center in photosystem II (Waggoner et al., 1989).

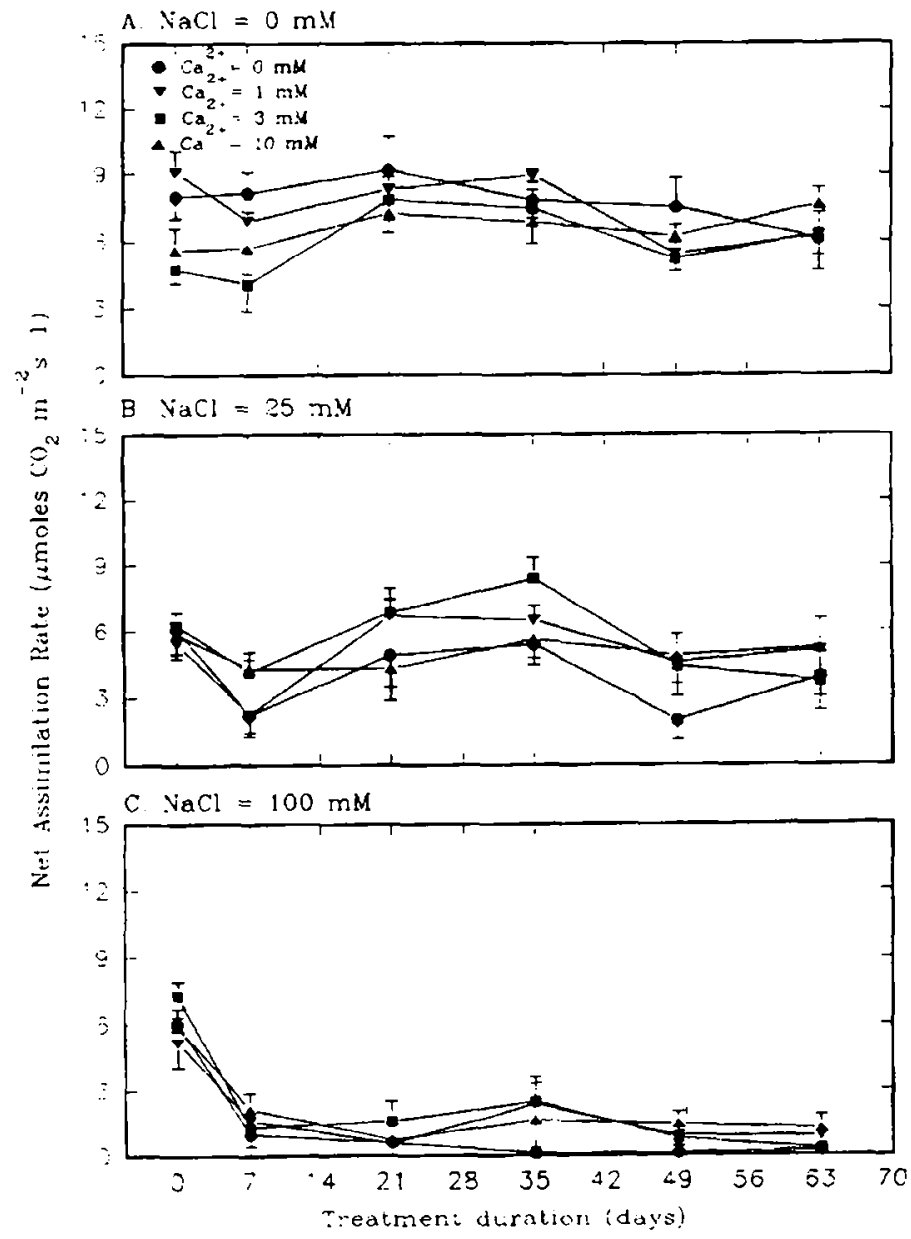

Fig. 5. Net assimilation rate of 'Tifblue' rabbiteye blueberries treated with $\mathrm{NaCl}$ and $\mathrm{Ca}^{2+}$. Vertical bars indicate SE.

Table 5. Influence of $\mathrm{NaCl}$ and $\mathrm{Ca}^{2+}$ treatments on stomatal conductance $\left(g_{s}\right)$. transpiration (E), and net assimilation (A) of 'Sharpblue' southern highbush blueberry plants.

\begin{tabular}{|c|c|c|c|c|}
\hline \multicolumn{2}{|c|}{$\begin{array}{c}\text { Treatment } \\
(\mathrm{mM})\end{array}$} & $\begin{array}{c}\mathrm{g}_{\mathrm{s}} \\
\left(\mathrm{mol} \cdot \mathrm{m}^{-2} \cdot \mathrm{s}^{-1}\right)\end{array}$ & $\underset{\left(\mathrm{mmol} \cdot \mathrm{m}^{-2} \cdot \mathrm{s}^{-1}\right)}{\text { E }}$ & $\frac{\text { A }}{\left(\mu \mathrm{mol} \cdot \mathrm{m}^{-2} \cdot \mathrm{s}^{-1}\right)}$ \\
\hline \multicolumn{5}{|c|}{$\mathrm{Na}^{+} \mathrm{Ca}^{2+}$} \\
\hline 0 & 0 & 0.139 & 3.22 & 4.49 \\
\hline 0 & 10 & 0.135 & 3.10 & 4.24 \\
\hline 25 & 0 & 0.103 & 2.68 & 4.10 \\
\hline 25 & 10 & 0.077 & 2.09 & 3.28 \\
\hline 100 & 0 & 0.034 & 0.57 & 0.87 \\
\hline 100 & 10 & 0.025 & 0.78 & 1.12 \\
\hline \multicolumn{5}{|c|}{ Source ${ }^{z}$} \\
\hline $\mathrm{Ca}^{2+}$ & & NS & NS & NS \\
\hline $\mathrm{Na}^{+}$ & & 0.0001 & 0.0001 & 0.0001 \\
\hline & ear & 0.0001 & 0.0001 & 0.0001 \\
\hline Time & & 0.0003 & 0.0160 & 0.0248 \\
\hline & lear & 0.0001 & 0.0368 & NS \\
\hline & adratic & 0.0707 & 0.0398 & 0.0267 \\
\hline $\mathrm{Na}^{+} x$ & time & 0.0001 & NS & 0.0510 \\
\hline
\end{tabular}

LProbability of a significant $\mathrm{F}$ value, $\mathrm{NS}=$ nonsignificant. $\mathrm{Ca}^{2+} \times$ time interaction, $\mathrm{Ca}^{2+} \times \mathrm{Na}^{+}$interaction, and $\mathrm{Ca}^{2+} \times \mathrm{Na}^{+} \times$time interaction were not significant.

yDays after salt application (treatment duration). 
As noted above with $\mathrm{g}_{s}$, effects of $\mathrm{NaCl}$ salinity on A were often more damaging than were the effects of $\mathrm{Na}_{2} \mathrm{~S} \mathrm{O}_{4}$; assimilation of plants given $100 \mathrm{~mm} \mathrm{NaCl}$ was only $28 \%$ of the A of unsalinized controls, while $\mathrm{A}$ of plants given $50 \mathrm{~mm} \mathrm{Na}_{2} \mathrm{~S} \mathrm{O}_{4}$ was $69 \%$ of unsalinized controls. Calcium supplementation was usually less effective with $\mathrm{NaCl}$ than with $\mathrm{Na}_{2} \mathrm{SO}_{4}$. This result suggests that the harmful consequences of $\mathrm{NaCl}$ salinity are due not only to the damaging action of $\mathrm{Na}^{+}$, as discussed previously, but also to the negative effects of $\mathrm{Cl}$.

Many fruit plants are sensitive to high concentrations of $\mathrm{Cl}^{-}$( Brown et al., 1953; Ehlig, 1965). Rabbiteye and southern highbush blueberry growth appeared to be reduced by high concentrations of Cl- (Wright et al., 1992). Net assimilation of grapevine ( Vitis vinifera L.) was inhibited under high leaf $\mathrm{Cl}^{\text {concentrations }}$ (Downton, 1977). Chloride-induced damage to RuBP carboxylase may be the primary cause of diminished A (Bongi and Loreto, 1989; Seemann and Critchley, 1985). Ziska et al. (1990) found that prolonged exposure to $\mathrm{Cl}$ led to reduced RuBP activity and RuBP carboxylase regeneration in plum ( Prunus salicina Lindl.). It is likely that salinity-induced decreases in blueberry growth are due to damage to the photosynthetic mechanism.

In general, $\mathrm{Ca}^{2+}$ supplementation ameliorated gas exchange of only the salinized 'Tifblue' rabbiteye blueberry. Low $\mathrm{Ca}^{2+}$ treatments $(1 \mathrm{~mm})$ were most effective in plants treated with $\mathrm{Na}_{2} \mathrm{SO}_{4}$. Blueberries are efficient $\mathrm{Ca}^{2+}$ accumulators, thus they may be damaged by high levels of $\mathrm{Ca}^{2+}$. Calcium levels within the cytoplasm must remain low to avoid precipitation of inorganic $\mathrm{P}$,

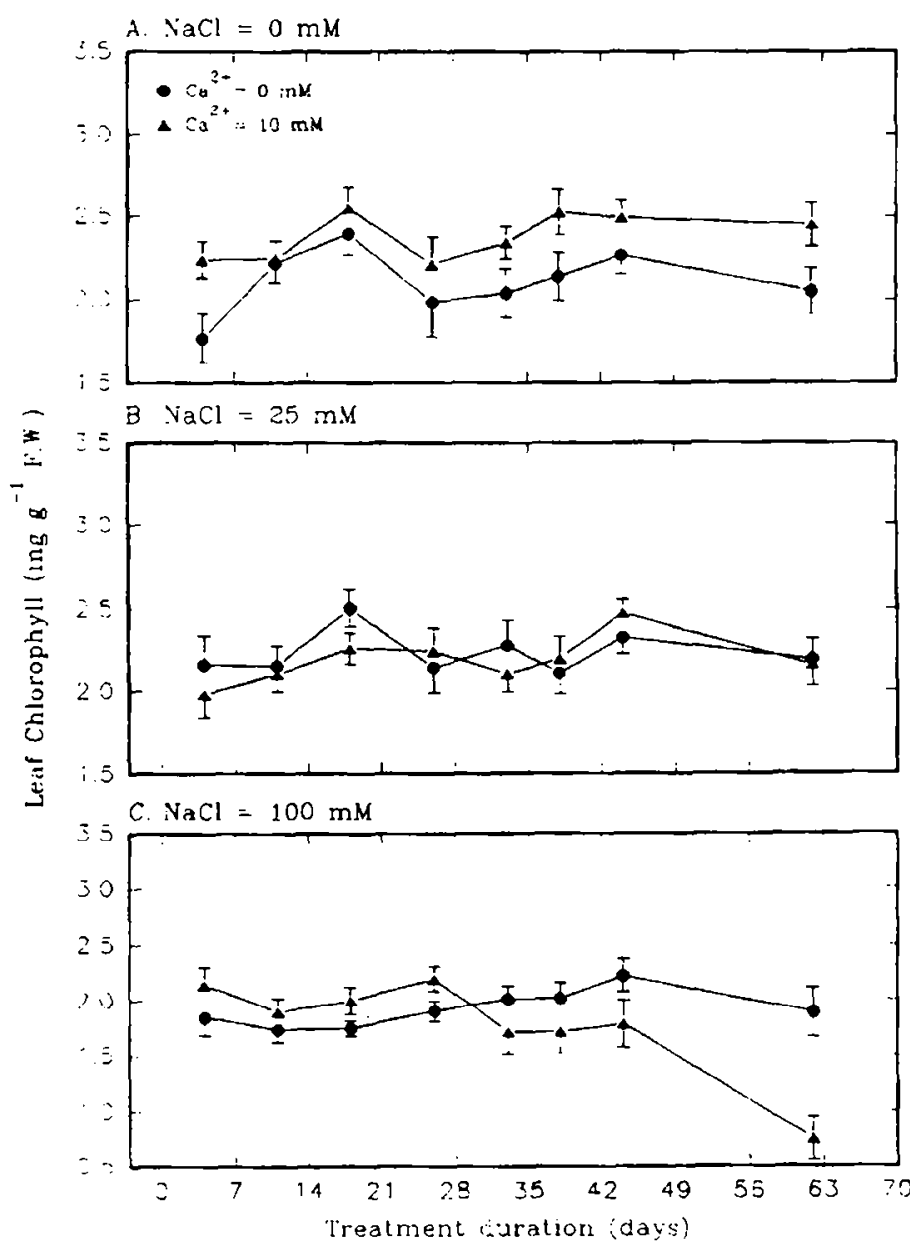

Fig. 6. Leaf chlorophyll concentration of 'Sharpblue' southem highbush blueberries treated $\mathrm{NaCl}$ and $\mathrm{Ca}^{2+}$. Vertical bars indicate $\mathrm{SE}$. competition with $\mathrm{Mg}^{2+}$, and/or uncontrolled activation or inactivation of enzyme systems (Marschner, 1986).

Reduced root $\mathrm{Na}^{+}$influx in the presence of adequate $\mathrm{Ca}^{2+}$ may account for some of the ameliorative effects of $\mathrm{Ca}^{2+}$ on cotton (Cramer et al., 1987). Further, LaHaye and Epstein (197 1) reported that $\mathrm{Ca}^{2+}$ reduced $\mathrm{Na}^{+}$translocation from bean roots to shoots. Similar phenomena may occur in rabbiteye blueberries, leading to the improved $\mathrm{A}, \mathrm{E}$, and $\mathrm{g}_{\mathrm{s}}$ found here. The inability of $\mathrm{Ca}^{2+}$ to counter NaCl-induced inhibition of gas exchange of 'Sharpblue' southern highbush blueberry (Table 5) indicates that this cultivar may be more sensitive to supplemental $\mathrm{Ca}^{2+}$, or more sensitive to $\mathrm{NaCl}$, and that the detrimental effects of Cl-may mask any putative amelioration from $\mathrm{Ca}^{2+}$ of $\mathrm{Na}^{+}$uptake.

Diminished gas exchange could also be caused by the degradation of chlorophyll, but, in this study, there was little difference in leaf chlorophyll concentration due to $\mathrm{Na}^{+}$or $\mathrm{Ca}^{2+}$ treatments (Figs. 3 and 6). Although leaf chlorophyll concentration of 'Tifblue' plants subjected to $100 \mathrm{mM} \mathrm{N} \mathrm{a}^{+}$was often less than that of plants subjected to 0 or $25 \mathrm{~mm} \mathrm{Na}^{+}$, this decrease was due predominantly to leaf necrosis, rather than chlorosis. 'Sharpblue' also exhibited more extensive necrosis than did 'Tifblue' when subject to 25 and $100 \mathrm{~mm} \mathrm{NaCl}$, but little chlorosis appeared. Chlorosis never approached the severity found in field plants irrigated with saline water, suggesting that $\mathrm{Na}^{+}$and $\mathrm{Cl}^{-}$are not responsible for such damage. Bicarbonates may lead to decreased Fe in the cell (Mengel and Geurtzen, 1986) and may be the cause of the chlorosis noted in the field.

In summary, $100 \mathrm{~mm} \mathrm{Na}^{+}$treatments led to decreases in $\mathrm{g}_{s}, \mathrm{~A}$, and $\mathrm{E} . \mathrm{NaCl}$ salinity led to greater reductions in gas exchange than did $\mathrm{Na}_{2} \mathrm{SO}_{4}$ salinity, presumably due to the additional effects of Cl-. Low $(1 \mathrm{~mm}) \mathrm{Ca}^{2+}$ supplements were often able to ameliorate the salinity damage, but $\mathrm{Ca}^{2+}$ was more beneficial when applied to plants in which salinity was induced with $\mathrm{Na}_{2} \mathrm{SO}_{4}$ than with $\mathrm{NaCl}$. Leaf chlorophyll concentration was not greatly diminished by $\mathrm{Na}^{+}$ or improved by $\mathrm{Ca}^{2+}$; decreases were due more to leaf necrosis than to leaf chlorosis. The cultivar 'Sharpblue' was more sensitive to $\mathrm{NaCl}$ salinity than was 'Tifblue'.

\section{Literature Cited}

Austin, M.E., T.P. Gaines, and R.E. Moss. 1986. Influence of soil pH on soil nutrients, leaf elements, and yield of young rabbiteye blueberries. HortScience 21:443-445.

Ballinger, W.E., A.L. Kenworthy, H.K. Bell, E.J. Benne, and S.T. Bass. 1958. Production in Michigan blueberry plantations in relation to nutrient-element content of the fruiting-shoot leaves and soil. Michigan Quart. Bul. 40:896-905.

Ben-Hayyim, G. and J. Kochba. 1982. Growth characteristics and stability of tolerance of citrus callus subjected to $\mathrm{NaCl}$ stress. Plant Sci. Lett. 27:87-94.

Bethke, P.C. and M.C. Drew. 1992. Stomatal and non-stomatal components to the inhibition of photosynthesis in leaves of Capiscum annum during progressive exposure to $\mathrm{NaCl}$ salinity. Plant Physiol. Plant Phys. 99:219-226.

Bongi, G. and F. Loreto. 1989. Gas-exchange properties of salt-stressed olive (Olea europea L.) leaves. Plant Physiol. 90:1408-1416.

Brown, J.W., C.H. Wadleigh, and H.E. Hayward. 1953. Foliar analysis of stone fruit and almond trees on saline substrates. Proc. Amer. Soc. Hort. Sci. 61:49-54.

Bush, E.W., D.M. Lancaster, and C.E. Johnson. 1990. Effects of water quality on field-grown rabbiteye blueberries. Louisiana Agr. 32: 14-15, 21.

von Caemmerer, S. and G.D. Farquhar. 1981. Some relationships between the biochemistry of photosynthesis and the gas exchange of leaves. Planta 153:376-387.

'Cramer, G.R., E. Epstein, and A. Läuchli. 1988. Kinetics of root elonga- 
tion of maize in response to short-term exposure to $\mathrm{NaCl}$ and elevated calcium concentration. J. Expt. Bot. 39:1513-1522.

Cramer, G.R., J. Lynch, A. Lauchli, and E. Epstein. 1987. Influx of $\mathrm{Na}^{+}$ $\mathrm{K}^{+}$, and $\mathrm{Ca}^{2+}$ into roots of salt-stressed cotton seedlings. Plant Physiol. 83:510-516.

Dinkelberg, W. and P. Lüdders. 1990. EinfluB jahrezeitlich unterschiedlither Na-Belastung auf die Photosynthese und Transpiration von Apfelbaumen. Gartenbauwissenschaft 55:130-135.

Downton, W.J.S. 1977. Photosynthesis in salt-stressed grapevines. Austral. J. Plant Physiol. 4:183-192.

Downton, W.J.S., B.R. Loveys, and W.J.R. Grant. 1990. Salinity effects on the stomatal behaviour of grapevine. New Phytol. 116:499-503.

Drew, M.C. and E. Dikumwin. 1985. Sodium exclusion from the shoots by roots of Zea mays (cv. LG 11) and its breakdown with oxygen deficiency. J. Expt. Bot. 36:55-62.

Drew, MC., P.S. Hole. and G.A. Picchioni. 1990. Inhibition by $\mathrm{NaCl}$ of net $\mathrm{CO}_{2}$ fixation and yield of cucumber. J. Amer. Soc. Hort. Sci. 115:472-477.

Drew, M.C. and A. Lauchli. 1985. Oxygen-dependent exclusion of sodium ions from roots of Zea mays (cv Pioneer 3906) in relation to salinity damage. Plant Physiol. 79:171-176.

Ehlig, C.F. 1965. Salt tolerance of raspberry, boysenberry, and blackberry. Proc. Amer. Soc. Hort. Sci. 85:318-324.

Greenway, H. and R. Munns. 1978. Mechanisms of salt tolerance in nonhalophytes. Ann. Rev. Plant Physiol. 31:149-190.

Gupta, A.S. and G.A. Berkowitz. 1989. Osmotic adjustment, symplast volume and nonstomatally mediated water stress inhibition of photosynthesis in wheat. Plant Physiol. 85:1040-1047.

Haby, V.A., K.D. Patten, D.L. Cawthon, B.B. Kresja, E.W. Neuendorff, J.V. Davis, and SC. Peters. 1986. Response of container-grown rabbiteye blueberry plants to irrigation water and soil type. J. Amer. Soc. Hort. Sci. 111:332-337.

Hope-Simpson, J.F. 1938. A chalk flora of the Lower Greensand; its uses in interpreting the calcicole habit. J. Ecol. 26:218-235.

LaHaye, P.A. and E. Epstein. 1971. Calcium and salt toleration by bean plants. Physiol. Plant. 25:213-218.

Lynch, J. and A. Läuchli. 1985. Salt stress disturbs the calcium nutrition of barley (Hordeum vulgare L.). New Phytol. 99:345-354.

Maas, E.V. and C.M. Grieve. 1987. Sodium-induced calcium deficiency in salt-stressed corn. Plant Cell Environ. 10:559-564.
Marschner, H. 1986. Mineral nutrition of higher plants. Academic Press, London.

Mengel, K. and G. Geurtzen. 1986. Iron chlorosis in calcareous soils. Alkaline nutritional condition as the cause for the chlorosis. J. Plant Nutr. 9:161-173.

Moran, R. 1982. Formulae for determination of chlorophyllous pigments extracted with N, $N$-Dimethylformamide. Plant Physiol. 69:1376-1381.

Parkinson, J.A. and S.E. Allen. 1975. A wet oxidation procedure for the determination of $\mathrm{N}$ and mineral nutrients in biological materials. Commun. Soil Sci. Plant Anal. 6:1-11.

Patten, K.D. 1988. Plant nutrition and fertilization, p. 9-1-9-10. In: M.L. Baker, K.D. Patten. E.W. Neuendorff, and C. Lyons (eds.). Texas blueberry handbook-Production and marketing. Texas Agr. Ext. Serv., The Texas Agr. Expt. Sta. and The Texas A\&M Univ. System. College Station, Texas.

Seemann, J.R. and C. Critchley. 1985. Effects of salt stress on the growth, ion content, stomatal behaviour and photosynthetic capacity of a saltsensitive species, Phaseolus vulgaris L. Planta 164:151-162.

Texas Dept. of Health. 1990. Chemical analysis of public water systems. Stock no. Z-123.

Waggoner, C.M., V.L. Peccoraro, and C.F. Yocum. 1989. Monovalent cations $\left(\mathrm{Na}^{+}, \mathrm{K}^{+}, \mathrm{Cs}^{+}\right)$inhibit calcium activation of photosynthetic oxygen evolution FEBS Lett. 244:237-240.

Wright, G.C., K.D. Patten, and M.C. Drew. 1992. Influence of salinity and supplemental calcium on the growth of rabbiteye and southern highbush blueberry. J. Amer. Soc. Hort. Sci. 17:749-756.

Wright, G.C., K.D. Patton, and M.C. Drew. 1994. Mineral composition of young rabbiteye and southern highbush blueberry exposed to salinity and supplemental calcium. J. Amer. Soc. Hort. Sci. (In press).

Yeo, A.R., S.J.M. Capom, and T.J. Flowers. 1985. The effect of salinity upon photosynthesis in rice ( Oryza sativa L.): Gas exchange by individual leaves in relation to their salt content. J. Expt. Bot. 36:1240-1248.

Zeevart, J.A.D. and R.A. Creelman. 1989. Metabolism and physiology of abscisic acid. Ann. Rev. Plant Physiol. 39:439-473.

Zhang, J., U. Schurr, and W.J. Davies. 1987. Control of stomatal behaviour by abscisic acid which apparently originates in the roots. J. Expt. Bot. 38:1174-1181.

Ziska, L.H., J.R. Seemann, and T.M. DeJong. 1990. Salinity induced limitations on photosynthesis in Prunus salicina a deciduous tree species. Plant Physiol. 93:864-870. 